\title{
Key events, October 1964 to June 1970
}

Date

1964

16 October

17 October

26 October

21-22 November

7-9 December
16 October

\section{Event}

First Chinese atomic weapon test

Election of Harold Wilson's first Labour government, with a majority of five

Wilson and economic ministers rule out devaluation

Labour government announces measures to restore economic stability, including a surcharge on imports

Defence conference and meetings at Chequers

Wilson, ministers and officials hold talks in Washington

1965

21 January

Patrick Gordon Walker, British Foreign Secretary, defeated in Leyton by-election

22 January

6-9 March

1 April

18-28 May

17-25 June

20 July

19 September
Michael Stewart appointed British Foreign Secretary

Wilson visits Berlin and holds talks in Bonn Wilson meets French President Charles de Gaulle and Prime Minister Georges Pompidou in Paris Republic of Germany

Commonwealth Prime Ministers' conference in London

Agreement between Britain and Germany on offset payments

Federal German elections; Ludwig Erhard remains Chancellor Queen Elizabeth II makes state visit to the Federal 
1966

7 March

$25 \mathrm{March}$

31 March

23-25 May

10 August

11 October

29 November

30 November

13 December

14-16 December
De Gaulle advises US President Lyndon B. Johnson of French withdrawal from NATO's military organisation

German Peace Note issued

Wilson's Labour government re-elected, with a majority of ninety-seven

Erhard holds talks in London

George Brown appointed British Foreign Secretary

President Johnson announces trilateral talks between the United States, Britain and Germany to report on NATO force levels, including offset payments

CDU/SPD 'Grand Coalition' under Kurt Georg Kiesinger replaces the Erhard government

Britain removes import surcharge

Kiesinger's policy statement stressing importance of French-German understanding and German support for Britain's entry into the EEC

1967

16 February

6-7 April

27-28 April

9 May

10 May

23-25 October

18 November

27 November

12 December

13-14 December

18-19 December
Wilson and Brown visit Bonn for talks about a possible British application for membership of the EEC

First meeting of the NATO Nuclear Planning Group

Agreement in trilateral talks on offset payments to Britain

NATO adopts ministerial guidance for the new strategy of flexible response

Formal application by Britain for membership of the EEC

Kiesinger holds talks in London

Devaluation of sterling

De Gaulle's press conference at which he expresses opposition to Britain's entry into the EEC

NATO Defence Planning Committee adopts new strategic concept of flexible response

NATO ministers agree Harmel study report

EEC Council of Ministers decides not to proceed with Britain's application for membership 
1968

$16 \mathrm{March}$

Michael Stewart appointed British Foreign Secretary

$28 \mathrm{March}$

Agreement between Britain and Germany on off-

1 July set payments

21 August

Britain signs the Non-Proliferation Treaty

27 November

Warsaw Pact forces invade Czechoslovakia

Britain ratifies the Non-Proliferation Treaty

1969

4 February

Meeting in Paris between de Gaulle and Nicholas Soames, British Ambassador (the so-called Soames affair)

11-13 February

Wilson holds talks in Bonn

24 February

Newly elected US President Richard Nixon visits

London for talks with Wilson

28 April

De Gaulle resigns as President of France

22 July

Agreement between Britain and Germany on offset payments

28 September Federal German elections

21 October

Willy Brandt appointed Federal German Chancellor in an SPD/FDP coalition

28 November Federal German Republic signs the Non-Proliferation Treaty

1 December At an EEG summit in the Hague, Brandt expresses strong support for Britain's application for membership

1970

2-4 March

Brandt holds talks in London

19 March

Meeting between Brandt and Willi Stoph, East

German Chairman of Ministers, in Erfurt, East

Germany

21 May Follow-up meeting between Brandt and Stoph in Kassel, West Germany

17 June Election defeat of Wilson's second Labour government

30 June Negotiations open for British membership of the EEC 